\title{
OS LIMITES DA ORALIDADE COMO FORMA 'ADEQUADA’ DE PRODUZIR VERDADE NO DIREITO
}

Ivan Furmann*

\begin{abstract}
SUMÁRIO: 1 . O PRINCÍPIO DA ORALIDADE NO PROCESSO: UM DIÁLOGO ENTRE O DIREITO E A ANTROPOLOGIA. 2. A SOLUÇÃO DA ORALIDADE PARA A CELERIDADE PROCESSUAL: UMA RESPOSTA INCOMPLETA. 3. A PRODUÇÃO DA VERDADE E O PRINCÍPIO DA Oralidade. 4. sensibilidade jurídica E Oralidade. 5. O QUE SE FALA, o que se transcreve E O QUE SE QUER OUVIR. 5.1. O que é dito e o que é escrito. 5.2. O que não se deve dizer para que não seja escrito e o que não se diz. 5.3. O que se quer ouvir nos tribunais: o processo como jogo. 6. O QUE SE PROCESSA AFINAL? 7. REFERÊNCIAS
\end{abstract}

RESUMO: A oralidade tem sido apontada pelo discurso jurídico oficial como garantidora de uma verdade fidedigna no processo. Entretanto, pesquisas etnográficas diversas têm demonstrado que a oralidade não garante em si a concretização de versões mais fidedignas em tribunais. A elaboração escrita da fala, a impossibilidade de externalização oral e a possibilidade de manipulação do que é dito são alguns exemplos que desconstroem o discurso jurídico e possibilitam pensar a oralidade em suas possibilidades fáticas.

PALAVRAS-CHAVE: Oralidade, antropologia jurídica, processo, verdade.

ABSTRACT: Orality has been identified by official legal discourse as a guarantor of truth in the process reliable. However, several ethnographic studies have shown that oral tradition does not in itself guarantee the achievement of more reliable versions in court. The development of written speech, the impossibility of outsourcing and the possibility of oral manipulation of what is said are some examples that deconstruct the legal discourse and enable thinking orality in their factual possibilities.

KEYWORDS: Orality, legal anthropology, process, truth.

\section{O PRINCÍPIO DA ORALIDADE NO PROCESSO: UM DIÁlOGO ENTRE O DIREITO E A ANTROPOLOGIA}

O Direito e a Antropologia são dois campos de conhecimento que têm dialogado pouco nos meios acadêmicos. A justificativa mais comum para tal fato é que o Direito tem uma finalidade prática, circunscrita a seus conceitos e a resolução de casos dentro de sua lógica (ou sistema), já a Antropologia tem um olhar de exterioridade, tentando explicar o mundo a partir de um olhar analítico, o que resulta em análises além dos critérios práticos de decisão que orientam o Direito e muitas vezes sem respostas finais. Em outras palavras, o Direito só tem interesse pelo conhecimento antropológico se o torna ferramenta para sua própria lógica (como se está fazendo atualmente com o conceito de "cultura"), e a Antropologia evita o uso de ferramentas intelectuais do Direito por não terem poder analítico, por serem conceitos que se explicam em si mesmos (como o conceito de propriedade ou crime) e, logo, limitados a seu próprio contexto cultural. Mas vale a pena dialogar com essas duas áreas? Clifford Geertz, em outro contexto, afirma que "só podemos comparar quando somos capazes de chegar ao coração do assunto, me parece, pelo menos neste contexto, o exato reverso da verdade: é através da

\footnotetext{
* Doutorando em Direito pela UFPR, Mestre em Educação, Bacharel em Direito. Professor do Centro Universitário Curitiba (Unicuritiba).
}

Revista de Estudos Jurídicos, a. 15, n. 22, 2011 
comparação, e de incomparáveis, que compreenderemos seja lá qual for o coração a que conseguirmos chegar" (GEERTZ, 1997, p. 354). O Direito e a Antropologia podem parecer totalmente distintos e incomparáveis, mas nesse confronto pode-se chegar ao coração de certos temas. A proposta aqui é discutir, confrontando o discurso do Direito e etnografias, um tema importante em comum a ambos os campos, a questão da oralidade como produtora de versões da realidade.

E para iniciar tal análise, deve-se conhecer como o discurso do Direito assimila a idéia de oralidade como um princípio processual. Um texto muito utilizado no Brasil para estudos de processo elucida ${ }^{1}$ :

(...) em seu sentido primitivo, a oralidade entre nós, representa um complexo de idéias e de caracteres que se traduzem em vários princípios distintos, ainda que intimamente ligados entre si, dado ao procedimento oral seu aspecto particular: os princípios da concentração, da imediação ou imediatidade, da identidade física do juiz, da irrecorribilidade das interlocutórias. (CINTRA, DINAMARCO e GRINOVER, 2006, p. 348).

Antes de explicar tal subdivisão de princípios e suas idéias inerentes, é interessante ressaltar que o Direito brasileiro tem suas raízes no direito português. E este, por conseguinte, recebeu influência de várias culturas diferentes. Sabe-se que o processo no Direito Romano antigo era basicamente oral. Assim como o Direito Germânico atribuído à tradição bárbara e seus famosos ordálios. (Ver HESPANHA, 2005, passim ou LOPES, 2008, passim). Entretanto, com a baixa idade média e a inquisição, desenvolveram-se formas de se estabelecer à verdade através do princípio da documentação. Tal princípio prevalece nos sistemas jurídicos ocidentais modernos, em especial após as revoluções burguesas, argumento que será desenvolvido adiante. Por ora, importa notar que o princípio da documentação é o princípio geral e a oralidade a exceção. Em geral, os processos são escritos, o que foi tipificado por Weber, em sua clássica tipologia do Direito, como direito racional-formal (WEBER, 1999, p. 1-153). Assim, a oralidade só é reivindicada, em doses variadas, como solução de dois problemas recorrentes do processo escrito: a) a demora dos procedimentos e b) a falta de pessoalidade do texto escrito. Para solucionar tais problemas a oralidade no processo aparece sobre os mais diversos rótulos e subprincípios.

O primeiro problema a ser solucionado pelo princípio da oralidade é percebido nos subprincípios da concentração dos atos e da irrecorribilidade das decisões interlocutórias. A concentração dos atos pretende com a oralidade reunir os atos processuais para que sejam realizados num único momento. Dessa forma o princípio da oralidade traria celeridade para o processo, servindo para simplificar sua sistemática.

\footnotetext{
${ }^{1}$ Apesar de discordar da perspectiva de "Teoria Geral do Processo", em que se naturalizam evidentes diferenças entre processo penal e processo civil, tal debate parece não gerar frutos de análise significativos para os objetivos do artigo. Assim, antes de uma teoria geral do processo, se analisa o discurso processualista
} 
De acordo com o princípio da oralidade, é salutar que exista sempre um expressivo número de manifestações das partes sob forma oral, principalmente na audiência, onde tais manifestações se devem concentrar, porque, dessa maneira, é possível se alcançar o julgamento da matéria posta em juízo com menor número de atos processuais (...) O princípio da concentração (...) contém a idéia de que todos os atos do processo, inclusive a sentença, devem realizar-se o mais proximamente possível uns dos outros, para que se possa proferir decisão justa." (WAMBIER, et. al., 2005, p. 78).

Para que a oralidade (...) surta todos os seus benéficos efeitos, torna-se necessária a redução de toda a instrução processual a um número mínimo de audiências, se possível a uma única audiência, onde se façam, desde logo, a instrução da causa e seu julgamento. (SILVA, 2006, p.68) ${ }^{2}$

Já com a irrecorribilidade das decisões interlocutórias pretende-se que as partes não possam discordar imediatamente das decisões judiciais, portanto não poderão também recorrer imediatamente. Com isso, o desfecho do processo ocorreria de forma mais rápida.

Para tornar-se realmente efetivo o princípio da oralidade, à medida que ele se vincula com o princípio da concentração, toma-se necessário impedir, tanto quanto possível, as contínuas interrupções no andamento do processo motivadas pelos recursos opostos pelas partes contra as decisões tomadas pelo juiz sobre os incidentes surgidos na tramitação da causa. Contra tais decisões, ditas interlocutórias, em nome da preservação do princípio da oralidade, ou não se concede recurso algum, ficando a matéria aí decidida imune à preclusão, de modo a ser apreciada eventualmente pelo tribunal do recurso interposto da sentença final, ou admite-se o recurso sem suspensão da causa, como acontece com o agravo de instrumento, que se processa sem prejuízo da tramitação do feito, podendo, no entanto, pela nova redação dada ao art. 527 do CPC, conceder, o relator do recurso, efeito suspensivo ao agravo de instrumento. (SILVA, 2006, p.68)

Importante ressaltar, portanto, que a oralidade se contrapõem ao formalismo do texto escrito. Esse formalismo pretende ser sinônimo de segurança, pois a manifestação escrita, por ser diferida, pode ser feita com vagar e cuidado. Essa segurança, porém, seria o motivo da lentidão do poder judiciário, já tantas vezes analisada. (Ver: ADORNO, PASINATO, 2007). Em resumo, a oralidade pode ser vista numa primeira face como remédio a lentidão processual.

A outra face da oralidade aparece como os subprincípios da imediação e da identidade física do juiz, em ambos a oralidade ganha contornos de verdade mais fidedigna, ou de verdade adequada. A oralidade serve nesses casos de remédio ao distanciamento das pessoas gerado pelo texto escrito. "Tem-se em vista a

2 Percebem-se expressões como "benéfico" e "vantagens" associadas à perspectiva da oralidade. Tais palavras destacam bem o que discurso jurídico acaba por creditar à oralidade. 
possibilidade de obter-se melhor resultado, conforme a lei e a verdade dos fatos, sempre que se prestigiar o princípio da oralidade." (WAMBIER, et. al. , 2005, p.77). Assim:

A oralidade seria, então, o instrumento capaz de possibilitar ao juiz não só ouvir, mas, especialmente, "sentir" as partes e as testemunhas e, por conseguinte, avaliar melhor as provas diante dele produzidas e formar, com mais certeza e precisão, o seu convencimento. (BAPTISTA, 2008, p. 38)

O melhor resultado na busca da verdade justifica-se pela credibilidade do contato entre as partes e o julgador.

A prevalência da palavra falada como meio de expressão, ao invés da escrita, é uma proposição que, em si mesma, nada representa, tendo apenas relevância para o processo à medida que. sendo empregada como instrumento para a comunicação entre o juiz e as partes, força necessariamente um contato pessoal entre o julgador e os litigantes, tornando possível ao juiz uma apreensão imediata do litígio, em sua versão original e autêntica, que lhe transmitem de viva voz os próprios contendores, dando-lhe, igualmente, o ensejo de presidir a coleta do material probatório com base no qual haverá de fundamentar a futura decisão, tendo um contato direto e pessoal com as partes e com as testemunhas, podendo, assim, avaliar-lhes a credibilidade das informações prestadas em juízo, certamente com muito maior segurança do que teria o julgador que apenas recebesse essa prova reduzida a um simples registro mecânico constante do processo, que, seguidamente, lhe chegaria às mãos muito tempo depois de prestado o depoimento. (SILVA, 2006, p. 66) (itálico nosso)

Essa crença no contato entre as pessoas como produtora da verdade, em especial na capacidade do juiz de buscar informação fidedigna, aparece primeiramente no subprincípio da imediatidade “(...) segundo o qual o juiz deve colher as provas direta e pessoalmente, sem intermediários." (WAMBIER, et. al. , 2005, p. 78). Neste sentido, deve-se observar

(...) que o juiz, a quem caiba proferir a sentença, haja assistido ao desenvolvimento das provas, das quais tenha de extrair seu convencimento, ou seja, que haja estabelecido contato direto com as partes, com as testemunhas, com os peritos e com os objetos do processo, de modo que possa apreciar as declarações de tais pessoas e as condições do lugar, e outras, baseado na impressão imediata, que delas teve, e não em informações de outros. O princípio não se acha apenas estritamente conjugado ao da oralidade, tanto que só no processo oral é passível de plena e eficaz aplicação, senão que, em verdade, constitui a essência do processo oral.” (CHIOVENDA, 1965, p. 53).

Este princípio exige que o juiz que deverá julgar a causa haja assistido à produção das provas, em contato pessoal com as testemunhas, com os peritos e com as próprias partes, a quem deve ouvir, para recepção de depoimento formal e para simples esclarecimento sobre pontos 
relevantes de suas divergências. (...) A proximidade temporal entre aquilo que o juiz apreendeu, por sua observação pessoal, e o momento em que deverá avaliá-lo na sentença é elemento decisivo para a preservação das vantagens do princípio, pois um intervalo de tempo excessivo entre a audiência e o julgamento certamente tornará difícil ao julgador conservar, com nitidez, na memória os elementos que o tenham impressionado na recepção da prova, fruto de sua observação pessoal, sujeita a desaparecer com o passar do tempo. (SILVA, 2006, p.67-8).

\section{No mesmo sentido o subprincípio da identidade física do juiz:}

(...) o princípio da identidade física do juiz, em razão do qual haverá de ser o mesmo juiz que preside a audiência, que colhe as provas orais o que de a sentença. Essa regra decorre do seguinte: o juiz que tiver contacto direto, na audiência, com as partes e testemunhas, tem mais e melhores condições de proferir uma sentença satisfatória, isto é, em que efetivamente se aplique o direito, do que aquele que não tenha presidido a audiência. (WAMBIER, et. al. , 2005, p. 78)

É o princípio segundo o qual o mesmo juiz que haja presidido a instrução da causa há de ser o juiz da sentença. Ora, se a oralidade, como se viu, tem por fim capacitar o julgador para uma avaliação pessoal e direta não só do litígio mas da forma como as partes procuram prová-lo no processo, não teria sentido que o juiz a quem incumbisse prolatar a sentença fosse outra pessoa, diversa daquela que tivera esse contato pessoal com a causa. (SILVA, 2006, p.68)

Tendo em vista tais subprincípios é possível afirmar que o princípio da oralidade no discurso jurídico corrente presta-se a duas funções. A primeira é de fornecer celeridade ao procedimento como um todo. A segunda é de garantir uma verdade mais fidedigna devido ao contato entre as partes e o juiz como pessoas. Tais funções variam conforme a área de aplicação do processo.

No processo civil, pode-se afirmar que no Brasil, a partir do Código de Processo Civil de 1939, adotou-se a oralidade como princípio na legislação, porém na prática, desde aquele período, o processo civil é misto. Com a aprovação do Código de Processo Civil de 1973 tal perspectiva de oralidade foi reduzida ainda mais (Cf. CINTRA, DINAMARCO e GRINOVER, 2006, p. 348-9).

No processo penal brasileiro a oralidade é mais limitada ainda.

Na nossa legislação processual penal ainda se mantêm as regras do procedimento escrito, com pálidos episódios decorrentes da oralidade e concentração. Uma importante exceção foi introduzida com o estabelecimento do rito sumaríssimo para o processo e julgamento das infrações penais de menor potencial ofensivo, de competência dos Juizados Especiais Criminais (art. 81 da Lei $n^{\circ}$ 9.099/95). O Código de Processo Penal também não consagra o princípio da identidade física do juiz, nem mesmo nos processos sumários, em que há certa concentração e imediatidade. Quando o art. 538, § $2^{\circ}$, alude ao juiz que "logo em seguida proferirá a sentença", quis se referir ao juiz 
como órgão do poder jurisdicional, pouco importando qual seja a pessoa física do magistrado no momento." (MIRABETE, 2000, p.44)

Os modelos processuais penal e civil não coincidem neste aspecto, no que decorre a crítica à possibilidade de uma teoria geral do processo (CF. LOPES JR., 2006, p. 107 e Ss.). Os objetivos da oralidade no processo civil tendem a ressaltar a celeridade do procedimento. Já no processo penal a celeridade processual nem sempre é vista com bons olhos. Para o processo penal o tempo do julgamento necessita ser "adequado". Nem excessivamente rápido, nem excessivamente lento.

Nesse cenário, juízes são pressionados para decidirem 'rápido' e as comissões de reforma, para criarem procedimentos mais 'acelerados', esquecendo-se que o tempo do direito sempre será outro, por uma questão de garantia. A aceleração deve ocorrer, mas em outras esferas. Não podemos sacrificar a necessária maturação, reflexão e tranqüilidade do ato de julgar, tão importante na esfera penal. Tampouco acelerar a ponto de atropelar os direitos e garantias do acusado. Em última análise, o processo nasce para demorar (racionalmente, é claro), como garantia contra julgamentos imediatos, precipitados e no calor da emoção (LOPES JR., 2006, p.29).

À continuação é fulminada a Presunção da inocência, pois a demora e o prolongamento excessivo do processo penal vão, paulatinamente, sepultando a credibilidade em torno da versão do acusado. Existe uma relação inversa e proporcional entre a estigmatização e a presunção de inocência, na medida em que o tempo implementa aquela e enfraquece esta" (LOPES JR., 2006, p.101).

Por isso, em geral, quando se propõe o princípio da oralidade no processo penal, este aparece como garantia, pretendendo destacar não a celeridade do processo, mas a possibilidade de construir uma versão fidedigna da realidade. Assim, a oralidade é uma garantia de diálogo contra o pré-julgamento do juiz.

(...) esse juiz transforma o processo numa encenação inútil, meramente simbólica e sedante, pois desde o início já tem definida a hipótese acusatória como verdadeira. Logo (...) esse juiz, ao eleger de início a hipótese verdadeira, não faz no processo mais que uma encenação, destinada a mascarar a hábil alquimia de transformar os fatos em suporte da escolha inicial. Ou seja, não decide a partir dos fatos apresentados no processo, senão da hipótese inicialmente eleita como verdadeira. A decisão não é construída a partir da prova, pois ela já foi tomada de início. É o prejuízo que decorre do pré-juízo. A situação é mais grave (...) na medida em que 'o que poderia restar de segurança é o livre convencimento, ou seja, retórica e contra-ataques, basta imunizar a decisão com um belo discurso'." (LOPES JR., 2006, p.82)

Em outro campo, a Constituição da República Federativa do Brasil de 1988 e a Lei 9.099 de 1995 estabeleceram diretrizes para simplificar o processo de pequenas causas a fim de garantir a prestação judiciária mais adequada para tais situações. Neste sentido a criação do juizado especial (tanto civil quanto penal) em 
que as causas não envolvem grandes valores ou envolvem crimes de pequeno potencial ofensivo (Cf. CINTRA, DINAMARCO e GRINOVER, 2006, p. 349).

$\mathrm{Na}$ esfera da justiça do trabalho também se busca adotar o princípio da oralidade como fundamento de toda sua dinâmica processual. A justificativa é a democratização e a publicização da esfera do trabalho. Assim, sendo as verbas trabalhistas, em geral, alimentares, ou seja, essenciais para o sustento alimentar do demandante, a demora para resolução das demandas poderia gerar consequiências irremediáveis (Cf. CINTRA, DINAMARCO e GRINOVER, 2006, p. 349). Assim, a aposta na celeridade processual da oralidade serve como remédio significativo para tais demandas urgentes.

Enfim, pode-se perceber que o princípio da oralidade permeia todo o sistema processual brasileiro, de uma forma ou de outra, justifica procedimentos e as atividades dentro do judiciário, bem como suas reformas e esperanças. A análise feita aqui não tinha como objetivo verificar divergências internas do próprio discurso, nem aprofundar tal análise, o objetivo era apenas demonstrar como o discurso recorrente se apresenta.

\section{A SOLUÇÃO DA ORALIDADE PARA A CELERIDADE PROCESSUAL: UMA RESPOSTA INCOMPLETA}

Tendo em vista o que se demonstrou anteriormente, percebe-se que o princípio da oralidade propõe-se a solucionar, ou auxiliar a solucionar, dois problemas do processo. O primeiro é a lentidão processual, o segundo e a falta de pessoalidade do processo escrito o que geraria uma distorção na busca de uma versão mais fidedigna dos acontecimentos. A segunda proposição merece uma análise aprofundada através do diálogo entre o Direito e a Antropologia trazendo produtivas reflexões. O primeiro também é salutar, mas nesse espaço ater-se-á a breve análise do assunto.

$\mathrm{O}$ princípio da oralidade quando associado à celeridade processual pretensamente evitaria que atos por escrito gerassem delongas propositais, principalmente atrasos mediante defesas escritas das partes, demandando provas específicas ou oitivas de testemunhas desnecessárias. Por isso, traduzindo o princípio da oralidade nos subprincípios da concentração dos atos e da irrecorribilidade das decisões interlocutórias, percebe-se que, nesse sentido, o princípio da oralidade é sinônimo de redução de encontros entre as partes e o juiz e de impossibilidade recursal de decisões interlocutórias ${ }^{3}$. Um processo comum na esfera penal ou civil pode estender-se em diversos encontros entre as partes e o juiz. As decisões do juiz nesses encontros podem gerar prazos para produção de provas, podem também desagradar uma parte que recorrendo aos tribunais pode conseguir a suspensão do processo até aquela decisão interlocutória seja julgada pelo tribunal.

3 Decisões interlocutórias são decisões não definitivas do juiz, por exemplo, uma aprovação ou desaprovação da produção de uma perícia em um documento supostamente falso. Esta decisão influenciará todo o processo por isso, em geral, o processo civil e penal permitem recursos aos Tribunais para que se possa tentar reverter a decisão inicial do juiz. 
Percebe-se, de forma um tanto quanto óbvia, que não é o uso da oralidade que está em jogo nessa espécie de debate. A oralidade não é sinônima de uso da fala, mas de simplificação processual, de diminuição de possibilidades de atos escritos até a decisão do juiz. A diminuição de atos escritos, sejam manifestações dos advogados das partes, produção de prova ou recursos até a sentença do juiz, não significa necessariamente maior utilização da fala. Um bom exemplo é a figura processual do agravo retido. ${ }^{4}$ Simplificando a possibilidade de recurso contra decisões interlocutórias, tal instrumento processual é feito oralmente e transcrito em ata da audiência. Os motivos do recurso devem ser expostos de forma oral e sucinta, porém o recurso será fundamentado e debatido nas "razões de recurso", peça escrita que será apresentada ao tribunal como preliminar das "razões de recurso" da apelação. Em outras palavras, num plano amplo esse instrumento processual visou concentrar as atividades orais e escritas em momentos apartados. Porém, a fala não foi o remédio para celeridade processual, e sim reordenação dos atos.

A reordenação de atos é a responsável pela agilidade da prestação jurisdicional. Uma prestação jurisdicional em que o juiz possa concluir o processo com o menor número possível de encontros. Essa conclusão revela o que está por detrás da celeridade que a oralidade traz: o subdimensionamento do Estado.

Vivemos a realidade de um Estado cujos serviços são
subdimensionados para uma demanda crescente de usuários que,
espero, tornem-se cada vez mais exigentes, pois esse
subdimensionamento retrata uma sociedade desigual, hierarquizada,
repressora e que precisa mudar para sobreviver. Esse
subdimensionamento não foi nem é ocasional, como também não foi
nem é planejado a frio, mas ele fez e continua fazendo parte de um
projeto que as elites construíram para o País, ao longo de séculos e
que se perpetua, baseado num modelo que patrimonializa o Estado,
inviabilizando, por isto, a socialização dos serviços públicos.
(SCHRITZMEYER, 1998, p. 55).

Para entender o que esse subdimensionamento significa basta observar os números apresentados pelo Conselho Nacional de Justiça (CNJ). Apenas a título de exemplo, verificamos que em pesquisa realizada em 2008 a justiça Federal no Brasil contava com 1478 juízes federais, sendo que o número de processos que tramitaram nas mais diversas instâncias da justiça federal chega ao número aproximado de 6 milhões, sendo proferidas em torno de 2 milhões de sentenças. $\mathrm{O}$ número de casos

\footnotetext{
${ }^{4}$ Pode-se ver tal modalidade de recurso em: BRASIL. Lei 5869 de 11de Janeiro de 1973 (compilada). Extraído de: http://www.planalto.gov.br/ccivil_03/Leis/L5869compilada.htm . Acesso em 15 de fevereiro de 2010. "Art. 523. Na modalidade de agravo retido o agravante requererá que o tribunal dele conheça, preliminarmente, por ocasião do julgamento da apelação. (Redação dada pela Lei $\mathrm{n}^{\circ}$ 9.139, de 1995) § 1o Não se conhecerá do agravo se a parte não requerer expressamente, nas razões ou na resposta da apelação, sua apreciação pelo Tribunal. (Incluído pela Lei no 9.139, de 1995) § 2o Interposto o agravo, e ouvido o agravado no prazo de 10 (dez) dias, o juiz poderá reformar sua decisão.(Redação dada pela Lei $n^{\circ} 10.352$, de 2001) § 3o Das decisões interlocutórias proferidas na audiência de instrução e julgamento caberá agravo na forma retida, devendo ser interposto oral e imediatamente, bem como constar do respectivo termo (art. 457), nele expostas sucintamente as razões do agravante.(Redação dada pela Lei $n^{\circ} 11.187$, de 2005)."
} 
novos por magistrado varia entre 2200 e 5000 por ano. Apesar do aumento progressivo do número dos magistrados, na taxa de $2,3 \%$ ao ano, a demanda e a taxa de congestionamento crescem. ${ }^{5} \mathrm{O}$ menor número de encontros entre o juiz e as partes visa aumentar o número de casos atendidos em menor tempo possível, com objetivos claros de desafogar o poder judiciário. Essa realidade pode ser observada também na justiça do trabalho e na justiça estadual na referida pesquisa.

A pesquisa quantitativa realizada pelo $\mathrm{CNJ}$, porém, pode ainda mascarar um quadro mais drástico, pois não se diferenciam os processos em que foram proferidas sentenças de mérito, ou seja, aquelas em que houve uma decisão efetiva do juiz sobre o objeto em disputa, e as sentenças que são proferidas extinguindo o processo por desistências (algumas podem ser motivadas pela demora) ou simplesmente por problemas processuais diversos como a prescrição (fim do processo por decorrência de tempo). A oralidade é conclamada na ânsia por procedimentos mais simples, que desafoguem o congestionado poder judiciário,

Um poder judiciário que convive com esse peso da "ineficiência" e mora tende a lidar com uma lógica de realização de seus próprios interesses e cotas. ${ }^{6} \mathrm{O}$ tempo para marcação da primeira audiência de um processo pode variar muito nos diversos ramos da justiça. No juizado especial estadual de Curitiba, por exemplo, varia entre 4 meses a 1 ano. Na justiça do trabalho pode variar de 3 meses até 1 ano. Tal demora força às partes a negociarem na audiência inicial sob pena de esperarem um grande período de tempo para os demais atos processuais e/ou, até mesmo, a terrível demora recursal. Em geral, quem tem maior poder econômico lida com tal característica do poder judiciário a fim de se beneficiar. Existem empresas no Brasil que preferem não cumprir obrigações trabalhistas para levá-las ao balcão de negociação judiciário e, em geral, levando vantagens econômicas substanciais. Nesse caso, a ameaça de demora recursal, e seus até 3 anos ou mais de espera, força os empregados a abrirem mão de direitos em favor da "celeridade". Ficam satisfeitos os empregadores e a justiça (com suas metas), porém, o empregado sai do fórum trabalhista sentindo-se injustiçado.

O problema da celeridade não tem relação direta com a questão do uso da fala nos processos, mas sim com uma cadeia complexa de causas e interesses que precisam ser investigados com cuidado. Até mesmo porque, atualmente, as fronteiras entre o escrito e o oral não são mais as mesmas do passado. $\mathrm{O}$ avanço da tecnologia (Cf. CASTELLS, 2006, p.413 e Ss.) tem quebrado as barreiras entre o

\footnotetext{
${ }^{5}$ Os dados completos podem ser verificados em: BRASIL, Conselho Nacional de Justiça. Justiça em números 2008: Variáveis e indicadores do poder judiciário. Extraído de: http://www.cnj.jus.br/images/imprensa/justica_em_numeros_2008.pdf. Acesso em: 16 de fevereiro de 2010.

${ }^{6}$ Interessante nesse sentido o programa denominado Meta 2. Tal programa tinha como um de seus dez objetivos julgar todos os processos distribuídos no poder judiciário antes de 31/12/2005. Para maiores informações: http://www.cnj.jus.br/index.php?Itemid=963 . Acesso em 16 de fevereiro de 2010. Existem relatos de juízes e funcionários do poder judiciário que abriram mão de férias para tentar cumprir algumas das metas traçadas. Para maiores informações: http://www.gazetadopovo.com.br/vidaecidadania/conteudo.phtml?id=918953 . Acesso em 16 de fevereiro de 2010.
} 
escrito e o falado, ${ }^{7}$ a tendência é que a tecnologia subverta a produção da informação, que não será apenas escrita ou oral, mas multimídia. Nesse sentido, não fará mais sentido debater a celeridade ou não do processo oral, pois o oral e o escrito estarão fundidos no mesmo meio de difusão.

\section{A PRODUÇÃO DA VERDADE E O PRINCÍPIO DA ORALIDADE}

Com a conclusão do capítulo anterior, apontava-se que o oral e o escrito serão fundidos com o desenvolvimento tecnológico. Porém, o segundo problema que o princípio da oralidade proporia a resolver no discurso jurídico corrente, tem outro viés, é a impessoalidade do processo escrito e sua incapacidade investigativa da verdade. É essa impessoalidade atribuída ao texto escrito, em contraposição a pessoalidade da palavra oral, que valoriza o uso da oralidade. Interessa perceber como tal discurso se estabeleceu como modelo de construção da verdade e por que o princípio da oralidade é em certo sentido periférico e, ao mesmo tempo, remédio para o modelo documental.

Para tanto, utilizar-se-á da ferramenta conceitual "modo de produção da verdade", emprestada de Michel Foucault, a qual não se pretende utilizar em toda sua complexidade, mas como ferramenta operativa para compreender certas realidades descritas nas etnografias analisadas adiante. Michel Foucault utilizou-se do conceito "modo de produção da verdade" no curso proferido na PUC do Rio de Janeiro em 1973, denominado "A verdade e as formas jurídicas". E logo na introdução do curso, apontava que seu projeto era demonstrar que "O próprio sujeito de conhecimento tem uma história, a relação do sujeito com o objeto, ou mais claramente, a própria verdade tem uma história" (FOUCAULT, 1996, p.8). A produção de verdade no discurso jurídico tem sua história.

(...) existem, na sociedade, ou pelo menos, em nossas sociedades, vários outros lugares onde a verdade se forma, onde um certo número de regras de jogo são definidas (...) As práticas judiciárias - a maneira pela qual, entre os homens, se arbitram os danos $\mathrm{e}$ as responsabilidades, o modo pelo qual, na história do Ocidente, se concebeu e se definiu a maneira como os homens podiam ser julgados em função dos erros que haviam cometido, a maneira como se impôs a determinados indivíduos a reparação de algumas de suas ações e a punição de outras, todas essas regras ou, se quiserem, todas essas práticas regulares, é claro, mas também modificadas sem cessar através da história - me parecem uma das formas pelas quais nossa sociedade definiu tipos de subjetividade, formas de saber e, por conseguinte, relações entre o homem e a verdade que merecem ser estudadas. (FOUCAULT, 1996, p. 11)

O modo de produzir verdade no Direito, e mais especificamente no processo, está relacionado ao discurso de saber poder de cada período histórico. Foucault analisa três momentos históricos específicos. O mundo grego, a idade

\footnotetext{
${ }^{7}$ Existem no mercado programas de reconhecimento de áudio, que processam as falas e transformam em texto escrito. Essa tecnologia ainda está em desenvolvimento, mas em poucos anos será comum. 
média e a modernidade. Para ele o modelo de produção da verdade desenvolvido na baixa idade média, ainda utilizado em algumas ciências, é o inquérito, "Foi para saber exatamente quem fez o quê, em que condições e em que momento, que o Ocidente elaborou as complexas técnicas do inquérito" (FOUCAULT, 1996, p.12).

O inquérito, porém, tem suas raízes gregas, desenvolvia-se através de uma técnica denominada "o símbolo". (Cf. FOUCAULT, 1996, p. 38) Tal técnica servia para realizarem confirmação de uma comunicação a longa distância. Geralmente quebrava-se uma peça de cerâmica em duas partes, distribuía-se tal peça aos dois interessados na mensagem e uniam-se as peças para confirmar sua autenticidade. Era um jogo em que se juntavam peças (como um quebra-cabeça), assim também a investigação de casos judiciários no mundo grego seguia essa técnica de investigação da verdade. A verdade era construída com uma união de várias versões da realidade. Para demonstrar tal forma de produzir verdade Foucault utiliza-se do exemplo da peça de Sófocles "Édipo-Rei", na qual vários depoimentos vão se unindo para construir uma versão sobre os acontecimentos da realidade. Tal forma de reconstituir um acontecimento era condizente com as práticas democráticas da sociedade ateniense. (FOUCAULT, 1996, p.54).

Tais práticas porém foram "soterradas" com a queda do mundo grecoromano. Na alta idade média européia, pela influência dos povos germânicos, os litígios jurídicos eram resolvidos através do jogo de provas (epreuve), conhecida no discurso da história do Direito como "juízos de Deus". Tal técnica não buscava reconstituir o passado mas solucionar o litígio. Para tanto se desenvolveram modos de proceder como o duelo, os juramentos e os famosos ordálios. ${ }^{8}$ (FOUCAULT, 1996, p.60). "No sistema de prova judiciária feudal trata-se não da pesquisa da verdade, mas de uma espécie de jogo de estrutura binária". (FOUCAULT, 1996, p.61). Essas práticas porém desaparecem entre os séculos XII e XIII, ressurgindo o inquérito, porém de uma forma bem diferente do inquérito grego. Essa nova técnica teria sido inventada para organizar a estrutura administrativa, em especial na igreja e nos monastérios. Iniciou-se com a chamada visitatio, onde os bispos visitavam suas dioceses para saber o que havia acontecido em sua ausência. (FOUCAULT, 1996, p.70). Tal procedimento era realizado através de uma investigação geral (inquisitio generalis) e depois, em caso de necessidade, uma investigação específica (inquisitio specialis). Foucault também destaca a produção de procedimento similar no império carolíngio, em especial na estruturação administrativa do poder soberano. Essas técnicas davam preferência ao procedimento escrito, “(...) impôs a escrita sobre a oralidade, constituiu o sistema cartorial” (LOPES, 2008, p.85).

(...) o processo canônico introduziu o escrito. Com ele, destaca-se em importância a figura dos notários. Além do juiz, é preciso contar com este redator oficial de fórmulas e atos judiciais, termos que são

${ }^{8}$ Ordálios constituem-se de provas contra a natureza, em que o demandado realiza um jogo para provar sua inocência. O mais famoso é o chamado juízo de fogo, em que o acusado seguraria por certo tempo em sua mão numa barra de metal ardente. Verificaria-se posteriormente, geralmente dois dias depois, se surgiram bolhas de queimadura nas mãos, o que provaria a culpa do acusado. Caso não surgissem bolhas seria a prova de inocência. 
reduzidos a escrito como memória (termos, autos) do processo. $\mathrm{O}$ notário cada vez mais secretaria o juiz em íntima cooperação e ligação com o desenvolvimento da controvérsia. No processo canônico, ele é um oficial da corte (tribunal) e não apenas um perito em escrever. (LOPES, 2008, p.87)

Os processos escritos em forma de inquérito da inquisição da igreja são exemplos singulares do que se pretende demonstrar, pois a inquisição utilizava-se notavelmente de processos escritos para suas investigações. É possível observar, por exemplo, no texto de 1376, denominado Manual do Inquisidor o uso da técnica escrita. "Se forem tão numerosos [os casos de delação] (...) o inquisidor mandará que escrevam num caderninho preparado para isso (...) as suas denúncias e o nome de quem denuncia, o seu próprio nome, os nomes das testemunhas e da indicação da cidade e aldeia em que vivem". (EYMERICH, 1993, p.103). Nesse texto existem regras específicas de como se procedem os registros de cada um dos atos. Cada acusação deve ser precedida de registro, “(...) o inquisidor manda colocar por escrito os termos exatos da denúncia, e "procede" (...) (EYMERICH, 1993, p.107), "tudo será registrado nos autos lavrados pelo escrivão" (EYMERICH, 1993, p.108).

Através do uso da palavra se pretendia garantir a 'correção' do procedimento, em geral, o uso da documentação servia como garantia da produção da verdade através da racionalização. Tal racionalização foi por muito tempo expressa no axioma jurídico "quod non est in auto non est in mundo", ou seja, o que não está no processo não está no mundo.

Talvez a diferença marcante do período final da idade média para o período pré-iluminista é que no primeiro prevalece o segredo processual. O processo da inquisição era escrito por ser secreto e, ao mesmo tempo, necessitar trânsito, controle além do espaço territorial imediato. Porém, "A racionalização foi acompanhada de uma perda: a da oralidade e da imediatidade da investigação. Elas só voltarão ao processo com as reformas do século XIX, quando o empirismo e o positivismo da ciência moderna entusiasmaram os juristas" (LOPES, 2008, p.90). O poder que a escrita confere aos procedimentos judiciais pode ser observado curiosamente, em análise do historiador Michel de Certeau ao comentar texto de Jean Lery descrevendo o contato entre os europeus e povos habitantes da América.

Quanto à escrita, seja santa ou profana, não apenas a desconheciam, como também, o que é pior, não possuíam quaisquer caracteres para significar qualquer coisa: no começo quando cheguei ao seu país para aprender-lhes a língua, escrevia algumas sentenças e depois as lia diante deles que julgavam fosse uma feitiçaria, e diziam um ao outro: Não é maravilhoso que este que ontem não saberia dizer uma palavra em nossa língua, em virtude deste papel que possui e que o faz falar assim seja agora entendido por nós? Essa é também a opinião dos selvagens da ilha espanhola, que nela foram os primeiros. Pois aquele que lhes escreveu a História diz assim: os Índios, sabendo que os espanhóis sem se ver nem falar um ao outro, apenas enviando cartas de lugar a lugar se entendiam desta maneira, acreditavam que eles tivessem o espírito de profecia ou que as missivas falavam: de maneira, diz ele, que os selvagens temendo serem descobertos e surpreendidos em falta, foram deste modo tão bem mantidos em seus 
deveres que não ousaram mais mentir nem roubar aos espanhóis. Por isto eu digo que quem quiser aqui ampliar esta matéria, ela se apresenta como um belo assunto tanto para louvar e exaltar a arte da escrita quanto para mostrar quanto as nações que habitam estas três partes do mundo, Europa, Ásia e África, têm do que louvar a Deus por estarem acima dos selvagens desta quarta parte dita América: pois em lugar de como eles, que nada podem se comunicar senão verbalmente, nós pelo contrário temos esta vantagem que sem sair de um lugar, por meio da escrita e das cartas que enviamos, podemos declarar nossos segredos a quem quisermos, estejam eles afastados até o fim do mundo. Além, também, das ciências que aprendemos nos livros, das quais os selvagens são, igualmente, destituídos de todo, ainda esta invenção de escrever que nós temos, da qual eles são também inteiramente privados deve ser colocada no rol dos dons singulares que os homens da parte de cá receberam de Deus. (LERY, Jean, 1558, apud CERTEAU, 1982, p. 214 e Ss.)

Essa feitiçaria poderosa dos europeus podia manter a continuidade no controle efetivado através do judiciário, tanto religioso como soberano, através da escrita, por grandes territórios. Os processos podiam ser relidos e os julgamentos revistos. Porém, Certeau ressalta que a pretensa universalidade da linguagem tem suas limitações.

A esta escrita que invade o espaço e capitaliza o tempo opõe-se a palavra que não vai longe e que não retém. Sob o primeiro aspecto ela não deixa o lugar de sua produção. Dito de outra maneira, o significante não é destacável do corpo individual ou coletivo. Não é, portanto, exportável. A palavra é, aqui, o corpo que significa. O enunciado não se separa nem do ato social da enunciação nem de uma presença que se dá, se gasta ou se perde na nominação. Não existe escrita senão onde o significante pode ser isolado da presença, ainda que os Tupinambá vejam nestes caracteres traçados sobre um papel uma forma enigmática de palavra, o ato de uma força; é certo que para eles a escrita é uma "feitiçaria", ou que para os selvagens da Ilha Espanhola "as missivas falem". (CERTEAU, 1982, p. 216)

A escrita, os termos jurídicos utilizados, a forma de processar, enfim, tudo está relacionado a uma forma de produzir a verdade. A escrita foi imaginada como corpo independente, para atravessar mares, porém ela só existe dentro das relações humanas. Nesse sentido, o escrito e o falado se aproximam. O que foi imaginado no inquérito era a separação do escrito e do falado, dando preponderância ao escrito como garantia de verdade. Essa imagem da escrita como garantia da verdade em oposição da fala próxima da mentira e do engano não tem fundamento empírico, tem fundamento histórico, tradicional.

E, essa tradição ocidental de documentação, registro escrito, tem uma guinada interessante com a noção de publicidade como garantia da verdade, que eleva o princípio ao seu auge no século XVIII e XIX. A Revolução francesa, por exemplo, reivindica através da forma escrita a "declaração dos direitos do homem e do cidadão" de 1789, na qual o texto escrito garante a própria noção de soberania. (HUNT, 2009, p. 113 e Ss). O princípio da documentação, da escrita, do 
formalismo do texto escrito ganha força na revolução francesa voltando-se contra as atrocidades do antigo regime. A legalidade foi um dos grandes lemas da revolução francesa e fundamentou toda a lógica do Direito penal moderno. A idéia de codificação, ou seja, legislação com caráter breve, simples e unitário, manuseável por qualquer cidadão, também é outro pilar para toda estrutura jurídica do século XIX. (BOBBIO, 1999, p. 66 e Ss.). Tal princípio foi assimilado pelas correntes denominadas 'positivistas' (ou formalistas) do Direito, que apontam a absolutismo da lei e a teoria da obediência. (BOBBIO, 1999, p. 131 e Ss.). No campo do processo, em conseqüência, a idéia de processo escrito vigorou em perfeita harmonia com essa estruturação do texto escrito como garantia contra a fala.

Porém, curiosamente, nessa mesma época, outro modo de produção da verdade foi se desenvolvendo, tal modo foi denominado por Foucault de exame ou sociedade disciplinar. Fundamenta-se especificamente na noção de análise, "no século XIX também se inventaram, a partir de problemas jurídicos, judiciários, penais, formas de análise bem curiosas que chamaria de exame (examen) e não mais de inquérito. Tais formas de análise deram origem à Sociologia, à Psicologia, à Psicopatologia, à Criminologia, à Psicanálise." (FOUCAULT, 1996, p.12). Segundo Foucault, esse modelo fundamenta-se na vigilância. As mudanças que se podem verificar no sistema penal no fim do século XVIII e início do XIX dão um indicativo importante. Foi no mesmo período da revolução francesa que começam a surgir teorias que invertem a perspectiva de crime. Até a revolução crime era relacionado a pecado, a falta. $\mathrm{O}$ crime se definia pelo conteúdo. Depois da revolução o crime é uma falta qualquer contra a sociedade. Essa falta contra a sociedade é definida em lei posta pela soberania popular (FOUCAULT, 1996, p.84). Para Foucault, Beccaria já expunha que o controle do crime não podia ser realizado apenas pelo judiciário, mas por uma série de poderes laterais, psiquiátricas, psicológicas, pedagógicas, médicas, etc. (FOUCAULT, 1996, p.86).

$\mathrm{O}$ inquérito era um procedimento pelo qual, na prática judiciária, se procurava saber o que havia ocorrido. Tratava-se de reatualizar um acontecimento passado através de testemunhos apresentados por pessoas que, por uma ou outra razão - por sua sabedoria ou pelo fato de terem presenciado o acontecimento - eram tidas como capazes de saber. (FOUCAULT, 1996, p.87-8)

[Na sociedade disciplinar], (...) não se trata de reconstituir um acontecimento, mas de algo, ou antes, de alguém que se deve vigiar sem interrupção e totalmente. Vigilância permanente sobre os indivíduos por alguém que exerce sobre eles um poder - mestreescola, chefe de oficina, médico, psiquiatra, diretor de prisão - e que, enquanto exerce esse poder, tem a possibilidade tanto de vigiar quanto de constituir, sobre aqueles que vigia, a respeito deles, um saber. Um saber que tem agora por característica não mais determinar se alguma coisa se passou ou não, mas determinar se um indivíduo se conduz ou não como deve, conforme ou não à regra, se progride ou não, etc. Esse novo saber não se organiza mais em torno das questões "isto foi feito? quem o fez?"; não se ordena em termos de presença ou ausência, de existência ou não existência. Ele se ordena em torno da norma, em 
termos do que é normal ou não, correto ou não, do que se deve ou não fazer." (FOUCAULT, 1996, p.88)

A questão central, portanto, não é mais reconstituir o que se passou, mas analisar a normalidade ou não do indivíduo, "a vigilância sobre os indivíduos se exerce ao nível não do que se faz, mas do que se é; não do que se faz, mas do que se pode fazer." (FOUCAULT, 1996, p.104). Quando se afirma que a oralidade pode garantir que o juiz avalie "(...) a credibilidade das informações prestadas em juízo, certamente com muito maior segurança (...)" (SILVA, 2006, p. 66) afirma-se que o juiz não deve mais apenas reconstituir o acontecimento através do jogo do inquérito de quebra-cabeça. O juiz precisa ser um tanto quanto psiquiatra, investigador, caçador. Ele precisa verificar a credibilidade da informação. Precisa verificar se a pessoa mente. Tem que julgar o que o indivíduo é. E o texto escrito não traz elementos suficientes para perceber se a pessoa mente ou não. Esse método das ciências humanas chamado por Ginzburg de método indiciário, no qual o investigador procura nos detalhes elementos negligenciados por pessoas não especializadas, indícios que constroem a verdade (GINZBURG, 1989, p. 143 e Ss.), faz parte de um modo da produção da verdade que invadiu todas as esferas sociais. O que explica o motivo pelo qual o direito processual acaba acatando a necessidade de averiguação oral do preso, do menor, da testemunha. A oralidade retorna como garantia de verdade no momento em que é necessário avaliar indícios além do escrito.

O discurso jurídico destaca a figura de Bentham como um defensor do processo oral, curiosamente, Foucault também cita Bentham e seu panóptico, modelo arquitetônico de prisão, como um exemplo do desenvolvimento da sociedade disciplinar.

CHIOVENDA (Instituições..., v. 3, p. 47), procurando destacar a superioridade da comunicação oral sobre a forma escrita, refere a seguinte passagem com que JEREMY BENTHAM, o eminente jurista inglês do século XVIII, combatia o processo escrito: "Não pode o juiz conhecer por suas próprias observações esses caracteres de verdade tão relevantes e tão naturais que se manifestam na fisionomia, no som da voz, na firmeza, na prontidão, nas emoções de medo, na simplicidade da inocência, no embaraço da má-fé; pode-se dizer que ele cerrou a si próprio o livro da natureza, e que se tornou cego e surdo em casos nos quais é necessário tudo ver e tudo ouvir...". (SILVA, 2006, p.66)

Portanto, a nova forma de produção da verdade condiz com a valorização da oralidade como modo mais coerente de busca da verdade. Se, atualmente, o modelo predominante é misto, ou seja, o princípio da oralidade e o da documentação coexistem, a oralidade aparece como remédio processual para potencializar a verdade graças à valorização do exame e das ciências humanas como forma de produção da verdade. E o problema que as etnografias levantam é exatamente este, até que ponto a oralidade "garante" verdade? 


\section{SENSIBILIDADE JURÍDICA E ORALIDADE}

Antes de discutir até que ponto o juiz pode investigar a veracidade de uma fala, é importante destacar que o Direito é uma parte de uma forma de imaginar a realidade, de representá-la. (GEERTZ, 1996, p.259). "Trata-se, basicamente, não do que aconteceu, e sim do que acontece aos olhos do direito; e se o direito difere, de um lugar para o outro, de uma época para outra, então o que os seus olhos vêem também se modifica". (GEERTZ, 1996, p.259). Portanto, a melhor pergunta não seria "até que ponto o juiz pode investigar a veracidade?", pois não se trata do que aconteceu, mas de como o juiz pode representar aquilo que acontece aos olhos do Direito. O que especifica as investigações das representações da verdade as sensibilidades jurídicas presentes em cada cultura.

Para entender tal idéia, vale destacar um detalhe interessante do processo brasileiro, em especial o processo penal. Roberto Kant de Lima faz interessante comparação entre o processo criminal brasileiro e o processo norte-americano. Inicialmente interessa notar algumas características do sistema norte-americano.

(...) São características deste sistema a presunção da inocência - pois só vão a julgamento os acusados que não se declaram culpados, a quem o Estado deve o due process of law - ou seja as arbitragens pelo júri nunca são obrigatórias para os cidadãos; o direito de não se incriminar, que impõe ao silêncio o significado da não culpabilidade, tendo como correlata a obrigação de dizer a verdade - tudo o que todos dizem em juízo deve ser verdade, sob pena de cometerem o crime de perjury; e a escolha, em comum acordo, dos "fatos" que devem ser discutidos e validados diante dos jurados, excluindo-se aqueles que não são consensualmente aprovados, através das exclusionary rules. O procedimento é todo oral e as falas são transcritas literalmente, servindo, a partir daí, de documentos para futuras discussões em outras instâncias. Assim, a oralidade, a explicitude e a literalidade são as suas características fundamentais. (LIMA, 2008, p.174-5).

Além da oralidade ser uma das principais características do sistema norteamericano, é interessante destacar que o acusado não pode mentir diante do juízo. Caso alguma de suas afirmações seja reconhecida como "mentira", o acusado será condenado também no crime de perjúrio. A defesa se faz pelo silêncio. No Brasil a mentira é um direito da defesa em sua estratégia processual.

(...) ao assegurar constitucionalmente o direito de o acusado não se auto-incriminar (direito ao silêncio), não se criminaliza, como no direito anglo-americano, a mentira dita pelo réu em sua defesa, o que implica não haver, no Brasil, a possibilidade de condenação por perjury, somente por falso testemunho (LIMA, 2008, p.174-5). (...) se o silêncio pode vir em prejuízo da própria defesa - como diz o brocardo, quem cala consente - o réu pode mentir livremente, pois apenas as pessoas verdadeiramente arrependidas confessam a verdade. O crime de "falso testemunho", diferentemente do crime de perjury, só pode ser alegado contra as testemunhas. (LIMA, 2008, p.181). 
É importante esclarecer, que a impossibilidade de condenação por perjúrio é entendida no sistema brasileiro como ampla defesa. Sendo o papel do juiz lidar com a possibilidade da mentira. E aqui começam os problemas.

Durante os interrogatórios da polícia, ou durante os julgamentos, são claras as instruções dos advogados brasileiros aos suspeitos, ou réus: se se declaram inocentes, mesmo tendo confessado na polícia, devem alegar tortura e manter o olhar tranqüilo encarando o juiz e os jurados, se se declaram culpados, devem manter o olhar baixo e guardar durante o julgamento expressão de arrependimento no rosto. (LIMA, 2008, p. 215). ${ }^{9}$

O juiz no sistema brasileiro, sabendo que o réu pode mentir como estratégia de defesa, e em geral o faz, despreza o interrogatório.

Assim, fazer perguntas chamadas capciosas, que induzem os declarantes em contradições, induzir respostas, duvidar, sempre, do que se diz, é a regra de nossas práticas burocráticas, judiciais e policiais. (LIMA, 2008, p. 217).

Quando não se despreza o interrogatório do réu, utiliza-o para conhecer o "caráter" do acusado. Essa é a lógica do sistema continental europeu, no qual “(...) se busca descobrir 'a' verdade, construída com a competência profissional, argúcia e inteligência dos juízes” (LIMA, 2008, p.208).

(...) os procedimentos brasileiros apontam para o privilegiamento da escrita, da interpretação e da implicitude. O juiz - não mais o Estado, como no inquérito policial - é visto como um agente extremamente esclarecido, quase clarividente, capaz de formular um julgamento racional, imparcial e neutro, que descubra não só a "verdade real" dos fatos, mas as verdadeiras intenções dos agentes. (LIMA, 2008, p.181).

A tradição norte-americana não é a única que convive de forma diferente com o problema da mentira no processo. Clifford Geertz relata a sua experiência etnográfica em relação à sensibilidade jurídica dentro do processo no mundo islâmico.

E essa identidade do correto e do real permeia a sensibilidade jurídica islâmica não só de uma forma abstrata, em tom e modo, mas também concretamente, como nos processos de deliberação e nos procedimentos. A adjudicação muçulmana não envolve simplesmente a conexão de uma situação empírica a um princípio jurídico; esses dois elementos já surgem juntos. Determinar um deles é determinar o outro. Os fatos são normativos: há menos probabilidade de que eles possam divergir do Bem, do que de que Deus possa mentir. Os homens, é claro, podem mentir, e, principalmente na presença de

${ }^{9}$ Um caso midiático e muito famoso nesse sentido é o caso de Suzane Von Richthofen em que foi orientada pelo advogado Denivaldo Barni Júnior para chorar diante das câmeras de televisão. Maiores detalhes podem ser vistos em: http://noticias.terra.com.br/brasil/interna/0,OI957594-EI306,00.html $<$ Acesso em 17 de fevereiro de 2010> 
juízes, o fazem com frequiência; e é aí que surgem os problemas. (GEERTZ, 1997, p.284).

Para resolver o problema da mentira no mundo árabe, a sensibilidade jurídica valoriza de forma mais acentuada a oralidade em detrimento ao texto escrito. A oralidade, porém , não é entendida como um meio de obtenção de informações, mas como personificação.

Como é sabido, pelo menos por aqueles cuja profissão é saber essas coisas, qualquer evidência apresentada diante de um tribunal muçulmano - isso é um tribunal regulado pelo sharia e presidido por um qãdi - é considerada como sendo oral, mesmo que inclua documentos escritos ou elementos materiais de prova. Só o testemunho falado saháda, "testemunhar" de uma raiz que significa "ver com nossos próprios olhos" - tem valor, e qualquer material por escrito que possa ser incluído, não é considerado como uma prova legal e sim como meras (e normalmente um pouco suspeitas) inscrições daquilo que alguém disse a alguém na presença de testemunhas moralmente confiáveis. Essa negação da validade legal de um ato escrito propriamente dito data dos períodos mais antigos do Islã, e nas fases formativas do direito islâmico a evidência escrita e também a evidência a que chamaríamos de circunstancial ou material, eram, com bastante freqüência, totalmente rejeitadas. A palavra pessoal de um muçulmano conhecido, "como escreveu Jeanette Wakin, "era considerada mais valiosa que um pedaço de papel abstrato ou uma informação sujeita a dúvidas e falsificações". Hoje em dia, quando a evidência escrita é aceita, mesmo que com certa relutância, a sua validade ainda é grandemente dependente do caráter moral do indivíduo ou indivíduos que, pessoalmente envolvidos em sua elaboração, emprestam-lhe sua própria autenticidade. Parafraseando Lawrence Rosen sobre práticas contemporâneas no Marrocos, não é o documento que toma o homem confiável, e sim o homem (e, em determinados contextos, a mulher) que dá autenticidade ao documento. (GEERTZ, 1997, p.285-6).

O que se pode aprender com o modelo islâmico é que a mentira e a verdade não estão relacionadas ao procedimento adotado. Os procedimentos norteamericano, brasileiro ou islâmico não são garantias de verdade. Nessas três sensibilidades jurídicas é possível mentir. E a mentira pode se passar como verdade nas três sensibilidades. A questão, porém, é o que se admite dentro do sistema judiciário. Na cultura islâmica a importância da confiabilidade do sujeito supera as desconfianças. No sistema norte-americano a confiabilidade na punição, na possibilidade concreta de investigação e na aceitação da negociação (risco do jogo) supera as desconfianças. No Brasil a desconfiança prepondera. O que se admite, portanto, com a oralidade são elementos exteriores a fala.

Mentir no Brasil, seja por escrito, seja através da fala, faz parte do cotidiano brasileiro no espaço público, é uma forma de defesa contra o ambiente público inóspito, “(...) o cidadão no caso brasileiro é o sujeito por excelência das leis impessoais (e universais), bem como do poder brutal da polícia, que servem sistematicamente para diferenciá-lo e explorá-lo impiedosamente (...)" 
(DAMATTA, 1991, p.72). A diferenciação trabalha com preconceitos raciais, de classe, etc. A análise de Roberto Da Matta sobre a "rua" no Brasil, demonstra que "De fato, falamos da 'rua' como um lugar de 'luta', de 'batalha', espaço cuja crueldade se dá no fato de contrariar frontalmente todas as nossas vontades. Daí por que dizemos que a rua é equivalente à 'dura realidade da vida'." (DAMATTA, 2001, p. 20). No Brasil, a mentira é uma estratégia, um modo possível de ser numa sociedade desigual, a mentira e a malandragem são formas de se lidar com a forma de se produzir verdade.

O malandro (...) seria um profissional do "jeitinho" e da arte de sobreviver nas situações mais difíceis. Aqui, também, temos esse relacionamento complexo e criativo entre o talento pessoal e as leis que engendram - no caso da malandragem - o uso de "expedientes", de "histórias" e de "contos-dovigário", artifícios pessoais que nada mais são que modos engenhosos de tirar partido de certas situações, igualmente usando o argumento da lei ou da norma que vale para todos (...) a malandragem, que não é só um tipo de ação concreta situada entre a lei e a plena desonestidade, mas também, e sobretudo, é uma possibilidade de proceder socialmente, um modo tipicamente brasileiro de cumprir ordens absurdas, uma forma ou estilo de conciliar ordens impossíveis de serem cumpridas com situações específicas, e - também - um modo ambíguo de burlar as leis e as normas sociais mais gerais. (DAMATTA, 2001, p.68-9).

A mentira ou a verdade não são dentro de um processo judicial resultado de um modo de proceder, mas, antes de tudo, um discurso que se prende a laços culturais. $\mathrm{O}$ modo de produção da verdade não engloba sujeitos meramente passivos e submetidos. Os diversos atores sociais lidam com a prática judicial interpretando seus limites e possibilidades de diversas formas. É nesse sentido que se pretende demonstrar como o uso da oralidade é muito mais complexo do que o discurso jurídico processual pretende expor. $\mathrm{E}$ os atores que sabem lidar melhor com o sistema conseguem resultados mais interessantes do que os atores que o sabem.

\section{O QUE SE FALA, O QUE SE TRANSCREVE E O QUE SE QUER OUVIR}

A dinâmica da oralidade, portanto, depende da forma de produzir a verdade, da sensibilidade jurídica e, o que será apresentado nesse tópico, de práticas e usos locais da palavra. Muitas etnografias demonstram que os procedimentos judiciais naturalizam o uso da fala, limitando as relações interpessoais que ela poderia possibilitar. É fácil perceber tal fato quando se compara o que se diz nas audiências com o que é selecionado para ser transcrito no processo. Também é possível perceber que as pessoas ao entrarem no poder judiciário deixam seus comportamentos cotidianos de lado e atuam com pretensões de serem bem sucedidos. Portanto, com um comportamento controlado por expectativas e experiências estigmatizadas que podem trazer resultados positivos para quem as seguem. 


\subsection{0 que é dito e o que é escrito}

Uma excelente etnografia para visualizar as diferenças entre o dito e o escrito nos processos judiciais é o trabalho de Lucía Eilbaum, numa investigação sobre os processos "fragados", que violavam direitos humanos em prol de produtividade, na justiça federal da Argentina. Apesar do contexto diferenciado, a justiça federal argentina, o comportamento em diversos procedimentos é muito similar ao brasileiro. Se no Brasil existe uma instrução criminal através do chamado inquérito policial, na Argentina o primeiro momento de um processo criminal ocorre nos chamados juzgados de instrucción. A primeira fase do procedimento criminal, é fundamentada no princípio inquisitorial e na formulação de autos, denominados pelos argentinos de "corpos do expediente", aonde se encontram os depoimentos iniciais, provas e, em muitas vezes, diversas papeladas burocráticas. (EILBAUM, 2006, p. 251). O principal responsável dessa primeira fase na Argentina denomina-se "secretario do juzgado", fazendo o papel do que aqui no Brasil se denomina delegado de polícia. A primeira questão interessante é o tratamento dado às informações dadas por funcionários públicos e pelos acusados que constam no corpo do expediente.

Como servidores do Estado, todo papel emitido ou reconhecido pelos policiais, através da assinatura e carimbo correspondentes se transforma em um "instrumento público". A particularidade desse instrumento é que outorga fé pública ao conteúdo do mesmo. De alguma forma, a fé pública seria uma crença do sistema na validade e veracidade do que passa ou é produzido pelas mãos dos seus operadores. Em função dessa particularidade, se presume que as informações do sumário policial são legítimas e verdadeiras. Para demonstrar o contrário, que "alguma coisa está fora do lugar", a versão do acusado é pouca coisa. Até porque, ao contrário da polícia, no seu interrogatório ele está legalmente autorizado a mentir. A presunção de verdade sobre a versão escrita da polícia se contrapõe de forma desigual com a presunção de mentira do depoimento do acusado. (EILBAUM, 2006, p.254)

A descrição da autora demonstra que na elaboração do corpo do expediente ocorre a despersonalização do caso. O único rastro de personalização é a assinatura dos participantes. Muitas vezes os modelos de escrita e a burocracia transforma os autos em mera formalidade. Porém, essa formalidade prepondera como formuladora da representação da realidade pelo direito. Um secretário de juzgado, perguntado sobre o uso do interrogatório do acusado, afirma em entrevista que " $\mathrm{O}$ que ele não declara não está no expediente. $\mathrm{O}$ que não está no expediente não existe. (...)". É novamente a reafirmação da máxima "quod non est in auto non est in mundo". Porém, quando a autora entrevista alguns secretários de juzgado sobre como procedem o interrogatório do acusado eles vão além, e apontam como formulam tal tarefa. 
da indagatória [interrogatório] e, finalmente, da forma em que é inscrita a versão do imputado. Um aspecto que me chamou a atenção na conversa com a secretária citada no início foi a forma em que apresentava a relação entre o que se diz e o que se escreve. A secretária disse que, quando o imputado diz alguma coisa que contradiz a versão da polícia, às vezes se pergunta para ele " $O$ senhor quer dizer isso?' E se ele não quer dizê-lo não o forçamos”. Nesse caso, "dizer isso" quer dizer escrever isso na ata. Ao tomar nota, o que se fala fica inscrito no expediente. Nessa visão, ao ficar inscrito no expediente, existe. Se por algum motivo o imputado não quer dizer ou escrever partes de sua versão, a sua palavra não tem valor nenhum. Ela só tem valor quando posta no papel, "embora você o escute". (EILBAUM, 2006, p.254)

$\mathrm{Na}$ fase de instrução criminal, na delegacia de polícia no Brasil por exemplo, o que se diz e o que se escreve varia conforme o encaminhamento dado ao responsável por sua elaboração. A etnografia de Mariza Correa sobre o processo criminal no Brasil aponta no mesmo sentido, afirmando que “(...) o delegado não se limita a informar a existência de um crime e as medidas adotadas pela polícia; vai além e explícita uma versão do acontecido - implícita mesmo quando os relatórios são breves, através da escolha dos fatos e testemunhas que merecem registro." (CORREA, 1983, p. 43). A prática da manipulação do escrito é comum em várias áreas do Direito. Os acordos elaborados, por exemplo, na esfera trabalhista ou na esfera civil, são ditados e formulados de forma a não demonstrar a animosidade para o acordo, a abordagem ou a negociação. $\mathrm{O}$ insulto moral, motivador de um litígio, fica encoberto pela resolução, muitas vezes meramente monetária do caso. (OLIVEIRA, 2002, p.31 e Ss.). Apenas se descreve o ressarcimento, esquecendo-se que muitas vezes litiga-se apenas para se demonstrar a correção de certa atitude.

Portanto, existe um controle de produção entre o falado e o transcrito, esse controle limita a própria oralidade como um todo.

\subsection{O que não se deve dizer para que não seja escrito e o que não se diz}

No mesmo trabalho, Lucia Eilbaum demonstra como alguns detalhes simplesmente não aparecem no processo. Por exemplo, o depoimento ou o interrogatório não é uma transcrição literal do encontro entre o agente público e a pessoa que tem o depoimento tomado. "Não se trata de uma tomada de notas integral da fala da pessoa, mas de uma transcrição por parte do instrutor sobre a fala do acusado e sobre o que lhe é perguntado." (EILBAUM, 2006, p.259). As notas vão variar conforme o estilo pessoal do funcionário e sua forma de dirigir os questionamentos. Como se havia destacado, esses depoimentos iniciais são produzidos na instrução do processo, ou seja, em sua fase inquisitorial. Por isso, muitas vezes as formalidades que atingiriam que parecem representar pessoalidade são apenas formalidades despersonalizadas pelo uso.

Ora, quando você lê o expediente sempre aparece como se a declaração tivesse sido prestada diante do juiz e do secretário. $\mathrm{O}$ 
formulário da ata se inicia sempre com o local e a data da declaração seguida da frase: "comparece diante de S.S. (Sua Senhoria) e Secretário Autorizante, uma pessoa...”. Por isso, embora não estejam presentes e apenas passem por um momento, o que não pode faltar de jeito nenhum é a assinatura de ambos. Se faltar, a declaração poderá se declarar nula. De alguma forma, a omissão do requisito formal da assinatura torna evidente a ausência que todos conhecem e aceitam pela própria rotina e dinâmica do trabalho. Desse modo, o juiz e o secretário podem ou não estar presentes, porque o que vale no expediente escrito é a sua assinatura. É como se esta corporificasse a presença deles. (EILBAUM, 2006, p.254)

Em outro momento a autora expõe uma situação tragicômica, em que uma das testemunhas aparece em juízo acusatório, tribunal oral e posterior a fase da investigação, e desmente conhecer o réu que havia confirmado conhecer no juízo de instrução. O juiz então lhe pergunta porquê havia confirmado que conhecia o réu no juízo de instrução. A testemunha responde que naquela declaração tem coisas que ela não disse. $O$ juiz então inquiri se a testemunha foi forçada a dar aquela declaração. Ela diz que não. $\mathrm{O}$ juiz, por fim, pergunta porque a testemunha assinou uma declaração que não tinha informações corretas. A testemunha afirma que assinou porque queria sair da lá (delegacia) o mais rápido possível (EILBAUM, 2006, 263-4). Nessa descrição aparece talvez um dos maiores problemas da transcrição de falas em processos, a impossibilidade de registrar as estratégias que estão além da fala, bem como as impressões que geram. Existem certas impressões, inclusive aquelas que o juiz utilizará para proferir suas sentenças, que não se transcrevem nos autos. Tal percepção poderá aparecer raramente na forma de termos técnicos, por isso a convicção íntima sobre a dissimulação do réu ou sobre a piedade para com ele, nunca apareceram expostos abertamente nos autos. E o que não foi dito pode ser mais importante do que o que foi dito.

Além dessa possibilidade, existem situações em que contextos sociais não permitem que se digam certas coisas. Isso pode se confirmar em outros contextos, e em outros níveis, através de assuntos inconfessáveis. Nas comunidades cariocas existe a figura do "cagueta". ${ }^{10}$ Tal figura expressa a traição, a falta de comprometimento com os segredos da comunidade. O uso do segredo comunitário talvez seja a característica mais explícita nas comunidades dominadas por poderes paralelos no Brasil, assim como também aparece no crime organizado e dentro dos presídios.

Além da vigilância recíproca entre presos e guardas, há outra forma de controle, velada mas reconhecida, no cárcere. É a "cagüetagem" interpresos — uma situação em que "todos se vigiam". A importância dos "cagüetas" (alcagüetes) para a

\footnotetext{
${ }^{10}$ Em Letra de Samba de Bezerra da Silva, denominada "Ele Cagueta com o Dedão do Pé" aparecem explicações sobre o tema: "Caguete é caguete mesmo / Vejam só como ele é (2x) / É que cortaram as duas mãos do safado / Ele agora cagueta com o dedão do pé! / É que sentaram a mamona nas duas mãos do canalha / Ele entrega os irmãos com o dedão do pé! / Ele é uma faca de dois gumes, / E também é formado em caguetação. / À noite ele tira plantão de coruja, / E no dia seguinte entrega os irmãos. / Já quebraram seus cornos várias vezes, / E já foi esculachado até por mulher. / Nem assim o patife não tomou vergonha, / Continua caguetando com o dedão do pé."
} 
administração do cotidiano carcerário encontra eco na atuação dos guardas. Não são poucos os rituais de extrema violência para a "extração de informações", como de planos de rebelião, emergência de grupos e lideranças, tráfico de drogas intramuros, etc. Em uma primeira visita ao $5^{\circ}$ Distrito Policial de Campinas, na qual conversamos com vários presos simultaneamente, o líder de cela apontou para um que estava no pátio, com o corpo todo cortado por gilete, afirmando: "... aquele ali é cagüeta, cagüetou na rua, não tem mole pra ele aqui não" (preso do $5^{\circ} \mathrm{DP}$ ). A represália à "cagüetagem" passa a ser considerada normal e a violência plenamente justificada: "Tinha safado, pilantra, que ninguém gosta de safado e pilantra que fica cagüetando os irmão, então saía assim, vai morrer. E matava" (preso da P1). (GOIFMAN, 1999)

No caminho até lá, entretanto, o telefone de Anísio tocou. A informação de que Lázaro era "cagueta" já teria chegado aos "irmãos" (do PCC), força ordenadora local. Eles telefonaram a José e mandaram que Lázaro retornasse, para um segundo "debate", agora na presença deles. Anísio retornou com o irmão, não tinha como não fazê-lo. Lázaro foi, então, submetido a outra discussão, dessa vez mais pesada. Os "irmãos" queriam executá-lo sumariamente - o "proceder" considera "correr com polícia" e "caguetar" pecados capitais. No entanto, talvez por respeitarem José, traficante antigo na região, e para evitar passar por cima de sua vontade, permitiram que Lázaro escapasse com vida. Mas não sem sofrer: a punição foi um espancamento, a ponto de ter ossos quebrados. Anísio o levou arrastado para casa e, uma hora depois, ele estava sendo colocado num ônibus rumo a uma capital do Nordeste. (FELTRAN, 2009, p.17)

Mentir nesses casos, inclusive na frente do juiz, é questão de sobrevivência num Estado subdimensionado que não consegue controlar a violência organizada, nem mesmo (e muito menos) nos presídios. O dito, portanto, não tem relação alguma com a verdade, mas com a sobrevivência.

A falta da oralidade também aparece oficializada em ritos processuais, como no caso do tribunal do Juri. O sistema do júri brasileiro impede a conversa entre os jurados.

[No Brasil] (...) os jurados se recolhem a uma sala secreta, sem a presença do réu, na companhia do juiz, de um serventuário da justiça que os acompanhou todo o tempo do julgamento para que não se comunicassem entre si nem com o público - de representantes da defesa e da acusação - o que difere da reunião secreta para discussão do processo e negociação do verdict dos doze jurados nos EUA, à qual ninguém pode assistir. Aí, novamente proibidos de discutir entre si, votam, secretamente, de acordo com sua consciência, colocando cédulas marcadas com sim ou não em uma urna em resposta a uma série de perguntas extremamente técnicas, que incluem o exame de agravantes e atenuantes, formuladas pelo juiz, com a anuência da acusação e da defesa (a quesitação), diferentemente do guilty/not guilty da arbitragem dos EUA. (LIMA, 2008, p.188)

Tal procedimento faz com que o júri seja decidido não pelo diálogo de populares sobre um caso, mas por situações alheias a fala. Algumas etnografias (SCHRITZMEYER, 2001; LOREA, 2003) já demonstraram que o tribunal do júri 
pode ser decidido por questões além das expostas nos autos como uma atuação elaborada de um advogado ou de um promotor. Schritzmeyer aponta a estratégia ritualizada num modelo teatral, na qual o bom ator tem maiores chances de ganhar, já Lorea aponta questões como preconceitos orientadores de um drama que não julga um fato, mas certa situação existencial de atores sociais. De qualquer forma, as duas etnografias demonstram que o não dito pode ser decisivo na conclusão de um caso, e mais, a falta de diálogo entre os jurados potencializa tal distorção do resultado do júri em relação ao que se planeja no discurso jurídico.

\subsection{O que se quer ouvir nos tribunais: o processo como jogo.}

Até agora foi possível perceber que existe manipulação na passagem do dito para o escrito, manipulação intencional ou não. Porém, outras vezes a manipulação pode estar na própria fala. Numa aula quando cursava graduação em Direito, um professor de processo do trabalho, que também era juiz do trabalho, contou um caso extremamente interessante. Contou que numa das audiências que presidia desconfiou de uma testemunha. Para comprovar sua teoria escutou atentamente o depoimento e perguntou a testemunha o horário de jornada de trabalho do requerente. A testemunha respondeu "das nove às dezessete horas". Como a audiência se desenrolava no período vespertino, no fim do depoimento o juiz perguntou "que horas são?" para a testemunha, que não hesitou em responder "três e meia". Então o juiz lhe perguntou: "engraçado, no depoimento você falou dezessete horas, porque agora não falou quinze horas?" A testemunha se incomodou com o comentário e mais algumas perguntas depois confessou que tinha combinado o depoimento com o advogado. Com orgulho, o professor-juiz contava que descobriu a testemunha falsa.

O jogo que o juiz jogou era um jogo de descoberta do mentiroso. Mas, provavelmente, muitas vezes o mentiroso ganhou esse jogo. E isso o próprio professor-juiz admitia. Bastaria saber falar o que se quer ouvir.

O Direito, nesse aspecto, apresenta-se como um jogo para os seus atores. Jogo sem objetivos sempre explícitos aos jogadores. "A possibilidade de haver um parentesco entre o direito e o jogo aparece claramente logo que compreendemos em que medida a atual prática do direito, isto é, o processo, é extremamente semelhante a uma competição, e isto sejam quais forem os fundamentos ideais que o direito possa ter." (HUIZINGA, 2000, p.59). Até mesmo porque todos os atores sociais participam da competição sobre certo aspecto.

Em estudo realizado no sistema de pequenas causas norte-americano, John Conley e William O’Barr apontam que a lógica decisória e as chances de vitória em determinado caso variam conforme a postura do demandante e do juiz. Os demandantes podem ser habituais ou leigos. Os demandantes habituais têm em geral maiores chances de vencer uma demanda porque aprendem os caminhos do poder judiciário, sua linguagem, a forma de expressar seus objetivos, etc. (CONLEY; O’BARR, 1990, p. 63 e Ss.) Já os litigantes ocasionais, denominados de litigantes orientados pelas relações, tem dificuldade em entender os caminhos do 
judiciário, bem como sua linguagem, ou mesmo expor suas demandas orientadas a possíveis sentenças judiciais (CONLEY; O'BARR, 1990, p. 59 e Ss.).

Entretanto, as chances de vitória na demanda podem mudar completamente quando se altera a orientação do juiz em relação ao seu papel. Em geral, os juízes seguem um modelo de aderência estrita a lei. Dessa forma, os termos técnicos e a linguagem técnica privilegiam os demandantes habituais (CONLEY; O'BARR, 1990, p. 85 e Ss.). Por outro lado, alguns juízes, minoritários, não aderem ao texto legal, mas apenas o utilizam como referência. Outros dão preferência à equidade como principal fonte de decisão. (CONLEY; O'BARR, 1990, p. 87 e Ss.). Quando isso acontece, o demandante habitual pode ter resultados inferiores ao demandante ocasional. Isso porque o juiz, de alguma forma, atua a fim de proteger o cidadão comum.

Essa pesquisa demonstra que dentro do poder judiciário existem certas formas mais favoráveis de agir, em que as chances de vitória serão maiores. Tudo dependerá do que o juiz "quer ouvir". O exemplo marcante de que saber jogar o jogo tende a beneficiar o demandante, vem da etnografia de Patrice Schuch junto a Vara da Criança e do Adolescente em Porto Alegre. Dois adolescentes que sofreram medidas "sócio-educativas" procedem de forma diferenciada frente ao juiz. O primeiro é Paulo, que procede de forma inadequada, mesmo tendo motivos significativos para revolta.

O juiz olhou fixamente Paulo e rispidamente disse-lhe para ele dizer seu parecer sobre a medida sócio-educativa, ao que Paulo respondeu um: Foi boa, sem maiores explicações. O juiz provocou: Para um cara que cometeu o crime que fizeste, que é repugnante [acentuou a entonação, arregalando os olhos, não tem mesmo outra coisa para falar. Houve um silêncio tenso. O juiz prosseguiu: Depois, a tua trajetória na instituição... Começaste fugindo, depois atacaste o monitor, em abril agrediste outro interno. Será que o que tu falas é coerente com a tua trajetória na FEBEM? Mais silêncio na sala, aumentando a tensão. A provocação estava no ar, mas Paulo não respondia. Até que o juiz referiu: Podes me ajudar a entender? O adolescente respondeu, irritado: Eu sou o culpado de tudo sempre. O que fizeram para mim lá dentro foi de graça. Eu sempre peço para ir ao DECA [Departamento Estadual do Adolescente, da Polícia Civil] e no IML [Instituto Médico Legal] e nunca me levam. Isso não conta. Dr. Rafael respondeu: O que conta é que você recebeu uma medida sócio-educativa por machucar pessoas. Na FEBEM você usou 'estoque' [armas artesanais] para isso, eu tenho aqui no processo. Então, você está sempre certo e a FEBEM sempre errada? O adolescente emendou: Eu não estou sempre certo, mas a FEBEM nunca foi certa para mim. (...) Após não ter recebido a progressão de medida, a mãe do adolescente chorou alto, enquanto Paulo levantouse e chutou a sua cadeira, gritando, com o rosto cheio de raiva: Juiz filho da puta... Vai tomar no cu, juiz desgraçado! O juiz assustou-se e o monitor da FASE segurou Paulo, conduzindo-o para fora da sala de audiências. O clima era, realmente, muito tenso na sala de audiências. $\mathrm{O}$ juiz disse, como a destacar a certeza de seu julgamento pela manutenção da medida: Ele estava bem pronto para sair... A mãe de Paulo o defendeu, chorando alto: Eu sei o que fizeram lá nele, eu sei que bateram nele. É o fim da picada isso aqui, é o fim da picada... O 
pai de Paulo tentou acalmar o filho, falando: O que é isso, guri? Os familiares saíram da sala e Dr. Rafael pediu para Márcia colocar um adendo, no termo de audiências, informando que ciente da decisão, o adolescente reagiu agressivamente, chutando a sua cadeira e proferindo impropérios ao juiz. (SCHUCH, 2005, p. 287-9).

O julgamento do juiz foi baseado em suas impressões do adolescente. Julgou-se a pessoa e não o fato imputado ao adolescente. Em outra situação, outro adolescente denominado Ricardo soube lidar melhor com o judiciário e com o juiz.

\begin{abstract}
Quando o juiz interrogou Ricardo para questionar se ele achava que valia mais do que uma bala de revólver, Ricardo respondeu: - Eu acho que acho que eu não valho nada. (...) Desde pequeno que eu acho que eu não valho nada, repetiu o adolescente com a voz engasgada, tornando o ambiente da audiência tenso. O juiz, experiente, continuou: E se tu ouvisses que tu vales para nós? Primeira vez, disse Ricardo. Mais silêncio, interrompido quando o juiz falou: Será? Tarde demais? São poucos os 'caras', mas têm gente que consegue... Tem gente que passou pelo que tu passaste, mas conseguiu mudar. Com esse brilho que tu tens. Tu tens um jeito de atilado, de inteligente. Talvez tu não percebas isto, mas isto tem grande valor. De alguma forma tu estás dizendo pra gente desistir de ti (Dr. Rafael, juiz do 3o JJ de Porto Alegre). $\mathrm{O}$ adolescente, inteligentemente, voltou a questão para o juiz: Desistir de mim não... Eu estou por vocês. O juiz insistiu, perguntando: E aí, o que é que a gente faz com esta primeira vez? Ricardo, jogando com as soluções do juizado, pediu: Me dá um curso para eu estudar de novo. Concedido o curso e acertado que Ricardo aceitaria esta "primeira vez", o juiz desligou o adolescente da medida de liberdade assistida. Ricardo saiu da sala de audiências sorrindo. Em nada lembrava o adolescente cabisbaixo da sala de audiências. (SCHUCH, 2005, p. 290)
\end{abstract}

Bom menino arrependido, mau menino infrator. O demandante que fala "o que se quer ouvir" acaba ganhando a demanda. Como num jogo, aquele que sabe jogar tem maiores chances de sucesso. Esse tipo de dramatização pode ter resultados terríveis. Um adolescente revoltado com um sistema que não o escuta. Outro adolescente que aprendeu que falar o que se quer ouvir (manipulando) resulta em demanda favorável. Parece óbvio que o juiz usou sua intuição acima de qualquer parecer técnico ou auxílio interdisciplinar. Não se deve condenar o juiz, mas se pensar em que ponto a oralidade pode ser uma armadilha ainda maior do que o processo escrito em se tratando de buscar uma verdade fidedigna. Pois os fatores de análise aumentam, a dificuldade para encontrar a verdade também.

\title{
6. O QUE SE PROCESSA AFINAL?
}

Afinal, pode-se chegar a uma conclusão em relação ao uso ou não da oralidade nos processos? Este artigo nunca teve a pretensão de responder essa pergunta, pois seu objetivo era desconstruir o discurso que a ligava a idéia oralidade aproximando-a da verdade. Em conseqüência, talvez, deve-se pensar se a maior ingenuidade do discurso jurídico não seria acreditar demais em si mesmo. Em suas 
próprias intuições e no valor de seus próprios atores. O Direito, na prática social, não irá se resumir a uma lógica circunscrita em seu próprio discurso. Assegurar a oralidade o papel de encontrar a verdade ou promover celeridade é confiar demais na teoria e ignorar a trama social. O déficit entre a teoria e a prática não está no uso da fala ou do texto escrito, mas na construção do próprio espaço público, de cidadania, que aproxima as instituições judiciais daqueles que delas demandam.

Os objetivos que permeiam a prática judiciária no Brasil variam conforme os demandantes, os funcionários e o objeto da demanda. O jogo que se processa no judiciário não tem regras fixas. A oralidade que pode servir para melhorar o processo, em alguns casos pode apenas mascarar um simulacro de justiça. Antes de se questionar o formato do procedimento, se os atores mentem ou não mentem na frente de um juiz, talvez devêssemos questionar qual tem sido o papel do poder judiciário e em que sentido tem cumprido tal papel.

O processo escrito e o processo oral podem chegar a soluções individuais diferenciadas, mas não mudam o pano de fundo do judiciário, não garantem um judiciário mais democrático e em, última análise, uma sociedade mais democrática. Não basta, portanto, alterar superficialmente os instrumentos processuais com idéias prontas. Deve-se estudar profundamente cada uma das áreas processuais e questionar se as mudanças podem melhorar o papel do judiciário. Deve o juiz avaliar pessoalmente o réu? Se for impossível não fazê-lo, como é possível explicitar e (talvez) controlar tal juízo? Respondendo tais dúvidas, talvez se possa questionar a necessidade de novos profissionais para auxiliar o juiz em sua avaliação pessoal do réu ou se o juiz deve ser preparado para tanto. E se, por fim, é necessário alterar os meios de se processar certas demandas e documentá-las. Pois, tanto o oral quanto o escrito, só tem sentido por meio das relações humanas.

\section{REFERÊNCIAS}

ADORNO, Sérgio; PASINATO, Wânia. A justiça no tempo, o tempo da justiça. Tempo soc., São Paulo, v. 19, n. 2, 2007.

BAPTISTA, Bárbara Gomes Lupetti. O princípio da oralidade visto sob uma perspectiva empírica: uma alternativa metodológica de pesquisa em Direito. Rio de Janeiro. Revista de Ciências Sociais. v. 14, n. 2, p. 33-58, 2008.

BOBBIO, Noberto. O positivismo jurídico: lições de filosofia do Direito. (tradução Marcio Pugliese, et al.). São Paulo: Ícone, 1999.

BRASIL, Conselho Nacional de Justiça. Justiça em números 2008: Variáveis e indicadores do poder judiciário. Disponível em: $<$ http://www.cnj.jus.br/images/imprensa/justica_em_numeros_2008.pdf >. Acesso em 16 de fevereiro de 2010.

CASTELLS, Manuel. A Sociedade em Rede. A era da informação: economia, sociedade e cultura. 9 $^{\text {a }}$ ed. São Paulo: Paz e Terra, 2006. 
CERTEAU, Michel de. A Escrita da história. (tradução de Maria de Lourdes Menezes). Rio de Janeiro: Forense Universitária, 1982.

CHIOVENDA, Giuseppe. Instituições de direito processual civil. v. 3. São Paulo: Ed. Saraiva, 1965.

CINTRA, Antonio Carlos de Araújo; DINAMARCO, Cândido Rangel; GRINOVER, Ada Pelegrini. Teoria Geral do Processo. 22 ${ }^{\mathrm{a}}$ ed. São Paulo: Malheiros Editores, 2006.

CONLEY, John; O’BARR, William M. Rules Versus Relationships: The Ethnography of Legal Discourse. Chicago: The University of Chicago Press, 1990.

CORRÊA, Mariza. Morte em família: representações jurídicas de papéis sexuais. Rio de Janeiro: Graal, 1983.

DAMATTA, Roberto. A Casa e a Rua: Espaço, cidadania, mulher e morte no Brasil. $4^{a}$ ed. Rio de Janeiro: Guanabara Koogan, 1991.

DAMATTA, Roberto. O que faz o brasil, Brasil. Editora Rocco, Rio de janeiro, 2001. EILBAUM, Lucía. O corpo do acusado: escrita, oralidade e direitos na justiça federal Argentina na cidade de Buenos Aires. In: GROSSI, Miriam Pillar, HEILBORN, Maria Luiza, MACHADO, Lia Zanotta (orgs.). Antropologia e direitos humanos 4. Blumenau: Nova Letra, 2006.

EYMERICH, Nicolau. Manual dos Inquisidores. Comentários de Francisco Pena. (tradução de Maria José Lopes da Silva). Rio de Janeiro: Rosa dos Tempos, 1993.

FELTRAN, Gabriel de Santis. A punição extra-legal nas periferias de São Paulo: situações etnográficas. In: 33o Encontro Anual da ANPOCS, 2009, Caxambu. Anais do 33o Encontro Anual da ANPOCS. São Paulo : Anpocs, 2009.

FOUCAULT, Michel. A Verdade e as Formas Jurídicas. Rio de Janeiro: Nau, 1996.

GEERTZ, Clifford. O saber local. Novos ensaios em antropologia interpretativa. (Trad. Vera Mello Joscelyne). $4^{\text {a }}$ ed. Petrópolis: Vozes, 1997.

GINZBURG, Carlo. Sinais: raízes de um paradigma indiciário. In: Mitos, emblemas, sinais: Morfologia e História (pp. 143-79). São Paulo: Companhia das Letras, 1989.

GOIFMAN, Kiko. Das "duras" às máquinas do olhar: a violência e a vigilância na prisão. São Paulo Perspec., São Paulo, v. 13, n. 3, Sept. 1999. Disponível em: $<$ http://www.scielo.br/scielo.php?script=sci_arttext\&pid=S0102$88391999000300009 \& \operatorname{lng}=\mathrm{en} \& n r m=i s o>$. Acessado em 23 de Fevereiro de 2010.

HESPANHA, António Manuel. Cultura jurídica européia: síntese de um milênio. Florianópolis: Fundação Boiteux, 2005.

HUIZINGA, Johan. Homo ludens. O jogo como elemento da cultura. São Paulo: Perspectiva, 2000.

HUNT, Lynn. A invenção dos Direitos Humanos - Uma história. São Paulo: Cia das Letras, 2009. 
LIMA, Roberto Kant de. Ensaios de antropologia e de Direito. Rio de Janeiro: Lúmen Iuris, 2008.

LOPES JR., Aury. Introdução crítica ao processo penal. $4^{\mathrm{a}}$ ed. Rio de Janeiro: Lumem Iuris, 2006.

LOPES, José Reinaldo de Lima. O direito na História. $3^{\text {a }}$ ed. São Paulo: Atlas, 2008.

LOREA, Roberto Arriada. Os jurados "leigos: uma antropologia do tribunal do júri. Dissertação (Mestrado em Antropologia Social) - Instituto de Filosofia e Ciências Humanas, Universidade Federal do Rio Grande do Sul. Porto Alegre, 2003.

MIRABETE, Julio Fabbrini. Processo penal. $10^{a}$ edição. São Paulo: Editora Atlas, 2000.

OLIVEIRA, Luís R. Cardoso de. Direito Legal e Insulto Moral. Rio de Janeiro: Relume- Dumará, 2002.

SCHRITZMEYER, Ana Lúcia Pastore. Controlando o poder de matar: uma leitura antropológica do Tribunal do Júri - ritual lúdico e teatralizado. Tese de doutorado. PPGAS - Programa de Pós-Graduação em Antropologia Social - FFLCH-USP Faculdade de Filosofia, Letras e Ciências Humanas da Universidade de São Paulo, 2001.

SCHRITZMEYER, Ana Lúcia Pastore. Descrença nas instituições públicas de resolução de conflitos. In: LERNER, Julio (org.). Cidadania, Verso e Reverso. São Paulo: Imprensa oficial, 1998.

SCHUCH, Patrice. Práticas de justiça: uma etnografia do "campo de atenção ao adolescente infrator" no Rio Grande do Sul, depois do Estatuto da Criança e do Adolescente. Porto Alegre, Universidade Federal do Rio Grande do Sul, Programa de Pós-Graduação em Antropologia Social, 2005. (Tese de doutorado).

SILVA, Ovídio A. Baptista. Curso de Processo Civil. Vol 1. $6^{\text {a }}$ ed. São Paulo: Editora Revista dos Tribunais, 2006.

WAMBIER, Luiz Rodrigues. ALMEIDA, Flavio Renato Correia. TALAMINI, Eduardo. Curso Avançado de Processo Civil. v.1. $7^{\text {a }}$ ed., São Paulo: RT, 2005.

WEBER, Max. Economia e Sociedade. Vol. 2. (tradução de Regis Barbosa e Karen Elsabe Barbosa). Brasília: Editora da Unb, 1999.

Recebido em: 13-09-2011

Avaliado em: 14-11-2011

Aprovado para publicação em: 05-12-2011 